Original Research Paper

\title{
Species Richness of Arboreal Beetle in Suranadi Nature Park Area and Its Potential as a Source of Science Learning in Elementary Schools
}

\author{
Mohammad Liwa Ilhamdi ${ }^{1^{*}} \&$ Muhammad Syazali ${ }^{2}$ \\ ${ }^{1}$ Department of Biology Education, Universitas Mataram, Mataram, Indonesia \\ ${ }^{2}$ Department Elementary of School Teacher Education, Universitas Mataram, Mataram, Indonesia
}

\author{
Article History \\ Received : December 04 $4^{\text {th }}, 2021$ \\ Revised : December 20 2021 \\ Accepted : December $29^{\text {th }}, 2021$ \\ Published : January $05^{\text {th }}, 2022$ \\ *Corresponding Author: \\ Mohammad Liwa Ilhamdi, \\ Department of Biology Education, \\ Universitas Mataram, Mataram, \\ Indonesia \\ Email: liwa_ilhamdi@unram.ac.id
}

\begin{abstract}
The beetle data in Suranadi Nature Park is still limited to species that move on the ground. This study aims to analyze: (1) the species richness of the arboreal beetle, and (2) its potential as a science learning resource in elementary schools. This type of research is descriptive research using a qualitative approach. Sampling was carried out on the type of habitat in Suranadi Nature Park, namely the forest area with rice fields and residential areas, air flow and the middle with a dense canopy. The collected samples were identified to determine the species. The richness of this species data is then analyzed qualitatively to determine its potential as a source of science learning in elementary schools. This is done by comparing the species richness data of beetles and elementary thematic books, then the topics are assessed according to their level. The results showed that the species richness of arboreal beetles in Suranadi Nature Park consisted of 19 species from 5 families. The species are Lema sp., Aulacophora similis, Aulacophora quadrimaculata, Aulocophora sp.1, Aulocophora sp.2, Aulocophora sp.3, Aulocophora sp.4, Aulocophora sp.5 Parchicola sp., Podontia sp., Altica cyanea and Lilioceris sp. (family Chrysomelidae), Mimela sp., Mimela langbianica (Rutelidae), Exopholis hypoleuca, Ontophagus taurus, Protaetia fruhstorferi (Scarabaeidae) and Leptura sp. (family Cerambycidae). This arboreal beetle species data may be used as a source for elementary science learning on $33 \mathrm{sub}$-themes. Of this number, there are two sub-themes that have very appropriate categories, namely Sub-theme 2 The diversity of living things in my environment and Sub-theme 1 Components of the ecosystem.
\end{abstract}

Keywords: species of beetle, Suranadi Nature Park, science learning resources, elementary school.

\section{Pendahuluan}

Kumbang (Insekta: Coleoptera) merupakan kelompok fauna yang paling beranekaragam di bumi. Ini menyebabkan kelasnya - insekta memiliki kekayaan spesies paling tinggi dibandingkan dengan kelas-kelas lain pada kingdom animalia. Jumlah spesies sebenarnya diperkirakan masih lebih besar dibandingkan dengan jumlah spesies yang telah berhasil dideskripsikan. Penemuan spesies baru secara kontinue dilaporkan oleh penelitian di berbagai belahan dunia, termasuk Indonesia (Ruzzier, 2018; Yoshitomi, 2014). Menurut Noerdijto, jumlah spesies dari kelompok kumbang yang ada di Indonesia adalah $10 \%$ dari total spesies yang ada di seluruh dunia (Shahabuddin et al., 2005). Spesies-

This article is licensed under a Creative Commons Attribution 4.0 International License. spesies ini tersebar di berbagai kawasan dan pulau yang ada di seluruh Indonesia. Di Hutan Pendidikan Gunung Walat, Jawa Barat telah berhasil ditemukan 16 spesies dari famili Cerambycidae (Sataral et al., 2015). Di Jambi dan Gunung Bwakareang Sulawesi Selatan ditemukan 28 spesies dari famili Cerambycidae dan 37 spesies dari famili Carabidae \& Staphylinidae (Atmowidi \& Noerdjito, 2016; Qodri et al., 2016). Di perkebunan kelapa sawit, Kalimantan Tengah ditemukan 24 spesies dari famili Scarabaeidae (Sa'roni et al., 2019). Di sungai Membramo Papua ditemukan 29 spesies (Rizal et al., 2019). Kekayaan spesies ini terus bertambah karena adanya pendeskripsian spesies baru (Gildenkov, 
2020). Selain di berbagai kawasan dan pulau tersebut, kumbang juga dapat ditemukan di kawasan Lesser Sunda Island seperti di Pulau Lombok.

Berdasarkan laporan hasil penelitian selama 13 tahun terakhir, telah berhasil ditemukan 52 spesies dari ordo Coleoptera di Pulau Lombok. Tahun 2008 ditemukan enam spesies dari empat lokasi berbeda yaitu Sesaot, Sembalun, Sapit dan Senaru (Beitr \& Serie, 2008). Dua spesies di antaranya dinamakan dari istilah Lombok, yaitu Lema (Petauristes) sumbawensis lomboki dan Hespera lombokana. Tahun 2012 dan 2013 dilaporkan masing-masing satu spesies yaitu Pachysternum apicatum dari famili Hydrophilidae dan Hydraena jacobsoni dari famili Hydraenidae (Fikacek et al., 2012; Jäch et al., 2013). Tahun 2014 tercatat ada tujuh spesies dari famili Curculionidae (Riedel et al., 2014). Tahun 2015 dilaporkan 26 spesies dari famili Staphylinidae (Löbl, 2015). Enam spesies di antaranya memiliki nama yang diturunkan dari istilah lokal, yaitu Baeocera batukoqensis, Sapitia lombokiana, Scaphisoma lombokense, Scaphisoma sapitense, Scaphisoma sesaotense dan Scaphobaeocera lombokensis. Dari famili Cerambycidae dilaporkan 11 spesies (Tatsuya \& Yaheita, 2015; Yokoi, 2015). Dua spesies di antaranya merupakan new record, dan namanya diturunkan dari istilah "Lombok". Spesies-spesies ini adalah Ceresium geniculatum, Ceresium diversum, Kunbir lombokiana lombokiana dan Kunbir lombokiana ikuoi. Ukuran kekayaan spesies-spesies tersebut dari enam famili.

Laporan hasil penelitian pada tahun 2020 menunjukkan bahwa jumlah famili dari ordo Coleoptera di Pulau Lombok lebih beragam dibandingkan dengan yang diketahui sebelumnya (Rohyani, 2020). Penelitian ini telah berhasil mencatat 22 famili baru yaitu Anthicidae, Bostricidae, Buprestinae, Carabidae, Cicindelidae, Cleridae, Coelometopinae, Cucujidae, Elatiridae, Erotylidae, Gyrinidae, Halticidae, Lycidae, Nabidae, Neanuridae, Nitidulidae, Passalidae, Ptiliidae, Scarabeidae, Silphidae, Stenebrionidae dan Tenebrionidae. Artinya bahwa: (1) ukuran kekayaan spesies yang sebenarnya lebih tinggi dibandingkan dengan yang telah dilaporkan, dan (2) spesies-spesies yang belum dilaporkan tersebar pada berbagai habitat di berbagai kawasan di Pulau Lombok. Hasil penelitian di Taman Wisata Alam (TWA) Suranadi membuktikan hal ini (Ilhamdi et al., 2021). Metode pit fall trap yang digunakan berhasil mencatat sebelas spesies dari delapan famili. Spesies-spesies ini adalah Agonum micans, Dinopelma leptaleum, Oxylobus meridionalis, Tachys blandus, Trycorinus rudepunctatus, Euspilotus assimilis, Paracymus subcupreus, Phanaeus vindex, Myrmex sp., Oxyporus maxillosus dan Platydema violacea. Kesebelas spesies tersebut juga merupakan catatan baru sehingga kekayaan spesies dari ordo Coleoptera di Pulau Lombok bertambah menjadi 63 spesies.

Ditinjau dari metode yang digunakan, ada potensi bahwa spesies-spesies dari ordo Coleoptera yang bersifat arboreal tidak tersampling. Selain itu, kekayaan spesies yang tercatat lebih kecil dibandingkan dengan kekayaan spesies dari ordo Lepidoptera (Ilhamdi et al., 2018) dan ordo Odonata (Ilhamdi et al., 2021). Ini tidak sesuai dengan fakta berdasarkan data empiris bahwa ordo Coleoptera merupakan takson dengan kekayaan spesies paling tinggi di antara kelas insekta dan bahkan pada kingdom animalia. Artinya bahwa masih ada spesies dari ordo Coleoptera yang menempati berbagai tipe habitat dan belum tercatat di TWA Suranadi. Ini tidak baik bagi manajemen konservasi kawasan. Dari aspek pendidikan, data kekayaan spesies dari ordo Coleoptera dapat dimanfaatkan sebagai sumber belajar kontekstual, terutama bagi peserta didik di Sekolah Dasar (SD) yang menurut teori dari Piaget masih didominasi oleh gaya berpikir konkrit (Domingo, 2021). Di samping itu, menggunakan potensi lokal seperti ini dapat meningkatkan literasi konservasi peserta didik (Sari et al., 2020; Sunarsih et al., 2020). Oleh karenanya, diperlukan penelitian dengan tujuan menganalisis kekayaan spesies kumbang arboreal dan potensinya sebagai sumber belajar sains di SD.

\section{Bahan dan Metode}

Penelitian deskriptif yang menggunakan pendekatan kualitatif ini dilaksanakan di TWA Suranadi (Gambar 1). Kawasan konservasi ini merupakan hutan sekunder yang dikelilingi oleh daerah urban. Berdasarkan Peraturan Bupati Lombok Barat Nomor 41 Tahun 2016, kawasan ini termasuk ke dalam desa wisata Suranadi di kecamatan Narmada. Pengumpulan sampel dilakukan pada tiga tipe habitat yaitu bagian tepi hutan yang berbatasan dengan sawah dan pemukiman penduduk, kawasan yang berbatasan 
dengan aliran air, dan bagian tengah hutan dengan kanopi yang rapat. Sampel kumbang arboreal dikoleksi dengan menjelajah tiga tipe habitat tersebut, dan memanfaatkan beberapa alat dan bahan seperti jaring serangga, plastik bening, tas kresek, kamera, botol bening dan alkohol $70 \%$. Pencarian sampel dilakukan pada setiap bagian tumbuhan yang memungkinkan ditemukannya kumbang, seperti permukaan atas dan bawah daun, tangkai daun, ranting dan batang tumbuhan dengan ketinggian sampai 2 meter dari permukaan tanah. Kumbang yang berhasil ditemukan difoto dan ditangkap untuk kebutuhan identifikasi spesies. Pengumpulan sampel sendiri dilaksanakan sebanyak lima kali ulangan dimasing-masing lokasi sampling.

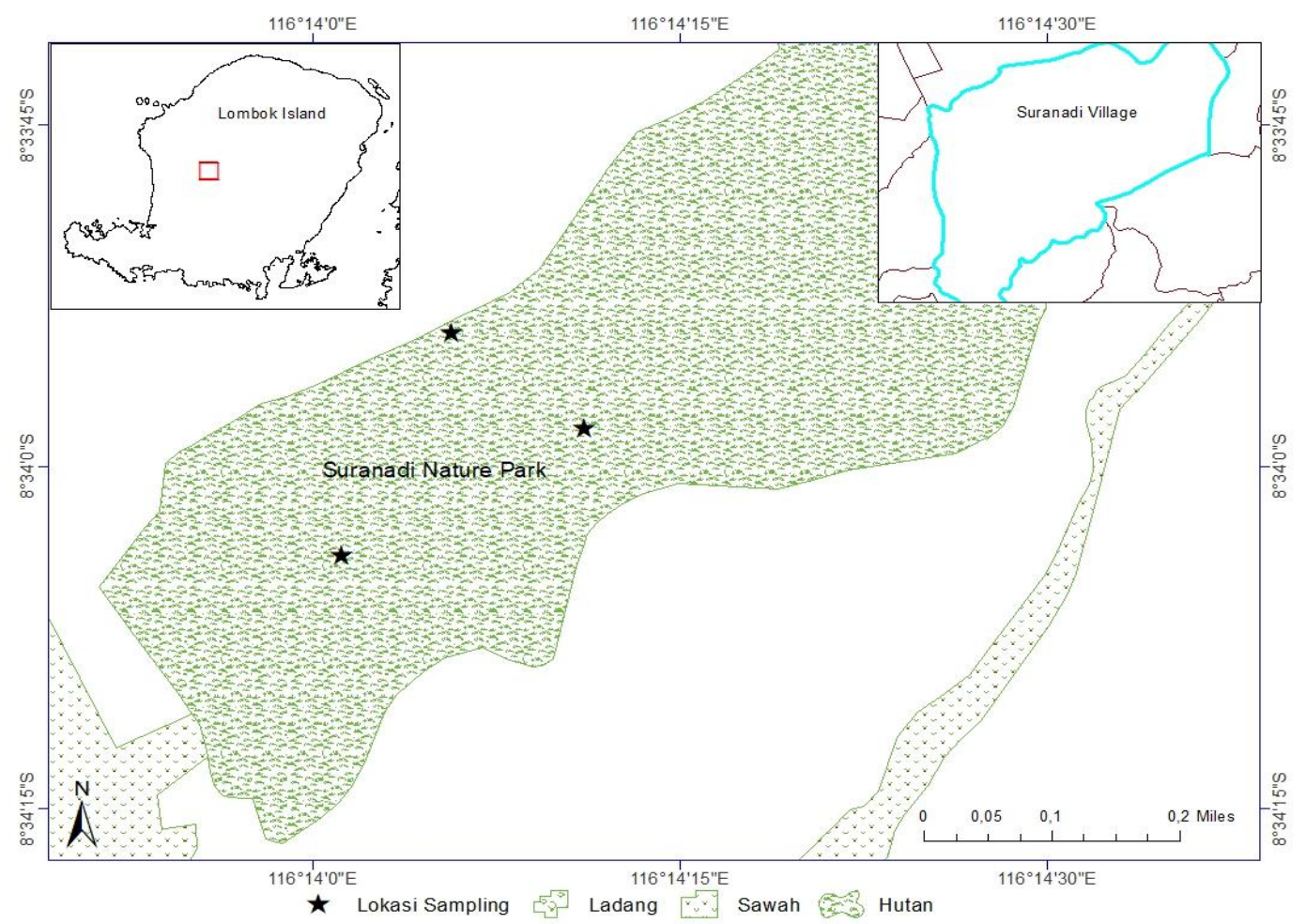

Gambar 1. Peta lokasi sampling

Sampel kumbang yang telah berhasil dikoleksi diidentifikasi untuk menentukan nama takson spesiesnya. Proses identifikasi menggunakan panduan identifikasi spesies berupa buku dan artikel ilmiah. Buku yang digunakan mencakup buku tentang pengenalan serangga dan kumbang (Borror et al., 1992; Dindal, 1990; Harding \& Moore, 1926). Adapun artikel yang digunakan mencakup artikel hasil penelitian tentang kumbang di Pulau Lombok, Pulau Bali, negara tetangga Singapura, dan kawasan Lesser Sunda Islands (Beitr \& Serie, 2008; Fikacek et al., 2012; Jäch et al., 2013; Löbl, 2015; Riedel et al., 2014; Yokoi, 2015). Data kekayaan spesies yang didapatkan dari proses identifikasi ini kemudian dianalisis secara kualitatif untuk mendapatkan informasi terkait potensinya sebagai sumber belajar sains pada peserta didik di SD. Metode yang digunakan adalah metode komparasi (Sulaeman et al., 2020). Data terkait kekayaan spesies dikomparasikan dengan dokumen berupa buku tematik yang digunakan di SD. Topik-topik potensial yang diperoleh melalui komparasi ini dinilai oleh tiga orang dosen pendidikan sains untuk mengetahui tingkat kesesuaian antara data hasil penelitian kekayaan spesies kumbang dengan topik-topik potensial tersebut.

\section{Hasil dan Pembahasan}

\section{Kekayaan spesies kumbang arboreal}

Penelitian ini telah berhasil merecord 5 famili dari ordo Coleoptera arboreal di TWA Suranadi. Famili-famili ini di antaranya 
Chrysomelidae (kumbang daun), Rutelidae, Scarabaeidae (kumbang scarab), Cerambycidae (kumbang sungut panjang) dan Erotylidae. Di antara famili-famili tersebut, Chrysomelidae merupakan takson famili yang memiliki kekayaan spesies paling tinggi yaitu dengan wakil sebanyak 12 spesies (Gambar 2). Famili Rutelidae diwakili oleh dua spesies. Famili Scarabaeidae diwakili oleh tiga spesies. Adapun famili lainnnya Cerambycidae dan Erotylidae - diwakili oleh masing-masing satu spesies. Jumlah famili ini lebih sedikit dibandingkan dengan jumlah famili yang ditemukan pada penelitian sebelumnya yang mencatat total delapan famili. Namun demikian, empat famili merupakan catatan baru di kawasan TWA Suranadi. Famili-famili ini adalah Chrysomelidae, Rutelidae, Cerambycidae dan Erotylidae. Ini berkaitan erat dengan mikrohabitat yang menjadi area sampling. Hal ini juga yang menyebabkan adanya perbedaan famili dengan kekayaan spesies paling banyak. Sebelumnya, famili yang paling kaya adalah Carabidae karena area sampling berupa permukaan tanah (Ilhamdi et al., 2021), sedangkan penelitian ini adalah Chrysomelidae karena fokus penelitian adalah kumbang arboreal.

Jika dibandingkan dengan famili yang ada di Pulau Lombok, famili Rutelidae merupakan catatan baru. Sebelumnya dilaporkan ada famili Chrysomelidae di Sesaot, Senaru dan Sembalun (Beitr \& Serie, 2008), Hydrophilidae dan Hydraenidae di Gunung Rinjani (Fikacek et al., 2012; Jäch et al., 2013). Staphylinidae di Sembalun, Pusuk, Bangko-bangko, Senaru dan Batu Koq (Löbl, 2015), Cerambycidae di Mangsit, Pusuk dan beberapa lokasi di Pulau Lombok (Tatsuya \& Yaheita, 2015; Yokoi, 2015), 22 famili dengan status new record yaitu Anthicidae, Bostricidae, Buprestinae, Carabidae, Cicindelidae, Cleridae, Coelometopinae, Cucujidae, Elatiridae, Erotylidae, Gyrinidae, Halticidae, Lycidae, Nabidae, Neanuridae, Nitidulidae, Passalidae, Ptiliidae, Scarabeidae, Silphidae, Stenebrionidae dan Tenebrionidae berdasarkan hasil pengamatan di daerah tambang pelangan, ekosistem mangrove Tawun, sawah Labuapi, kebun Sesaot dan hutan lindung Jeruk Manis (Rohyani, 2020). Adanya new record pada takson famili ini menunjukkan bahwa keanekaragaman dari ordo Coleoptera di Pulau Lombok lebih tinggi dibandingkan dengan yang telah diketahui sebelumnya. Keberagaman pada takson famili mengisyaratkan keberagaman pada tingkatan takson yang lebih rendah yaitu genus dan spesies.

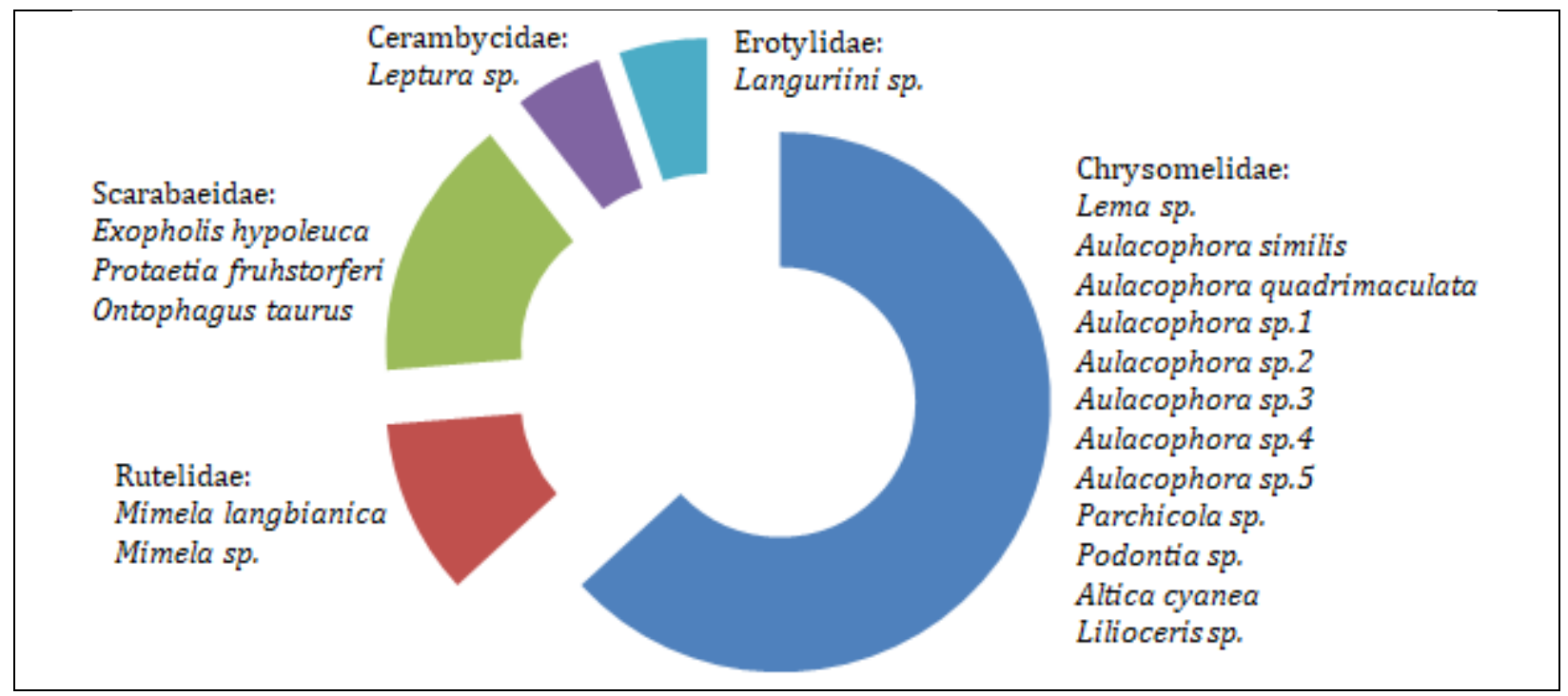

Gambar 2. Kekayaan spesies dari kumbang arboreal di TWA Suranadi

Spesies dari kumbang arboreal yang telah berhasil tercatat di TWA Suranadi adalah 19 spesies. Spesies-spesies ini adalah Lema sp.,
Aulacophora similis, Aulacophora quadrimaculata, Aulacophora sp.1, Aulacophora sp.2, Aulacophora sp.3, Aulacophora sp.4, 
Aulacophora sp.5 Parchicola sp., Podontia sp., Altica cyanea dan Lilioceris sp. (famili Chrysomelidae), Mimela langbianica, Mimela sp. (Rutelidae), Exopholis hypoleuca, Ontophagus taurus, Protaetia fruhstorferi (Scarabaeidae) dan Leptura sp. (famili Cerambycidae). Secara khusus, kekayaan spesies kumbang dari famili Chrysomelidae di TWA Suranadi lebih tinggi dibandingkan dengan kekayaan spesies yang pernah tercatat di Sesaot, Senaru dan Sembalun (Beitr \& Serie, 2008), namun dari famili Cerambycidae masih lebih terbatas karena sebelumnya telah dilaporkan sebanyak 11 spesies dan empat spesies di antaranya merupakan spesies baru (Tatsuya \& Yaheita, 2015; Yokoi, 2015). Empat spesies tersebut adalah Kunbir lombokiana lombokiana, Kunbir lombokiana, Merionoeda wayani dan Merionoeda (Merionoeda) lombokiana. Sampel spesies kumbang arboreal yang ditemukan di TWA Suranadi dapat diamati pada Gambar 3 berikut ini.

Jika ditotal, maka di TWA Suranadi telah tercatat 30 spesies dari ordo Coleoptera. Kekayaan spesies ini masih berada di bawah proporsi umum yang berlaku antara kumbang dan Arthropoda lain. Ini dikarenakan setidaknya kekayaan spesies kumbang sebesar $40 \%$ dari kekayaan spesies insekta dan predominan pada kerajaan hewan (Ettema et al., 1998). Dari ordo Lepidoptera, kupukupu, telah tercatat 40 spesies dari famili Hesperidae, Lycaenidae, Nymphalidae, Papilionidae dan Pieridae (Ilhamdi et al., 2018). Dari ordo Odonata, telah tercatat 18 spesies dari famili Aeshnidae, Chlorocyphidae, Coenagrionidae, Libellulidae, and Platycnemididae (Ilhamdi, Idrus, Santoso, et al., 2021). Dari Arthropoda tanah selain kumbang, telah tercatat 22 spesies dari takson Araneae, Blattodea, Diptera, Homoptera, Hymenoptera, Orthoptera dan Thysanura (Ilhamdi \& Syazali, 2021). Ini belum termasuk berbagai spesies dari ordo-ordo lain yang tergabung dalam kelas Hexapoda, terutama spesies-spesies yang aktivitasnya lebih bnayak dilakukan di tumbuhan atau spesies-spesies yang bersifat arboreal.
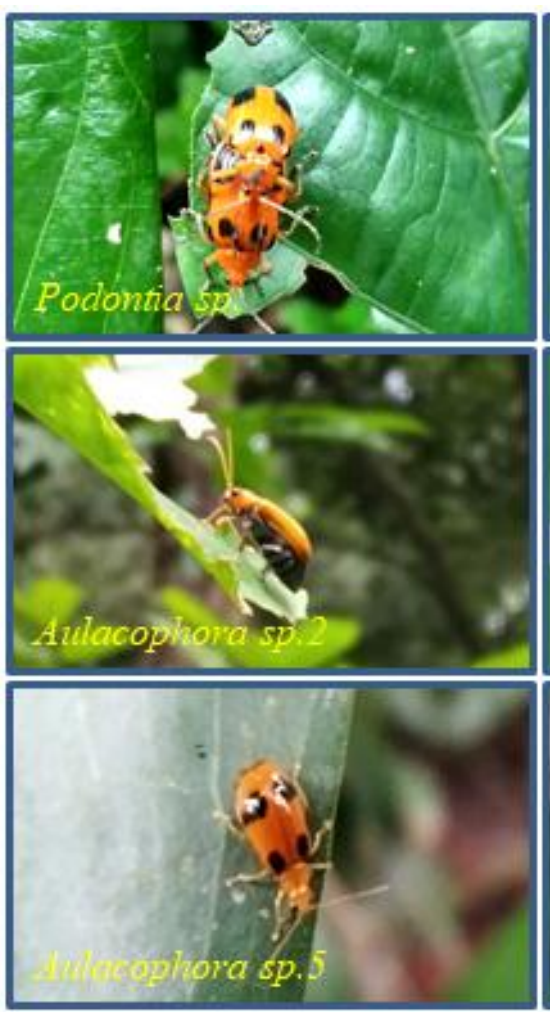
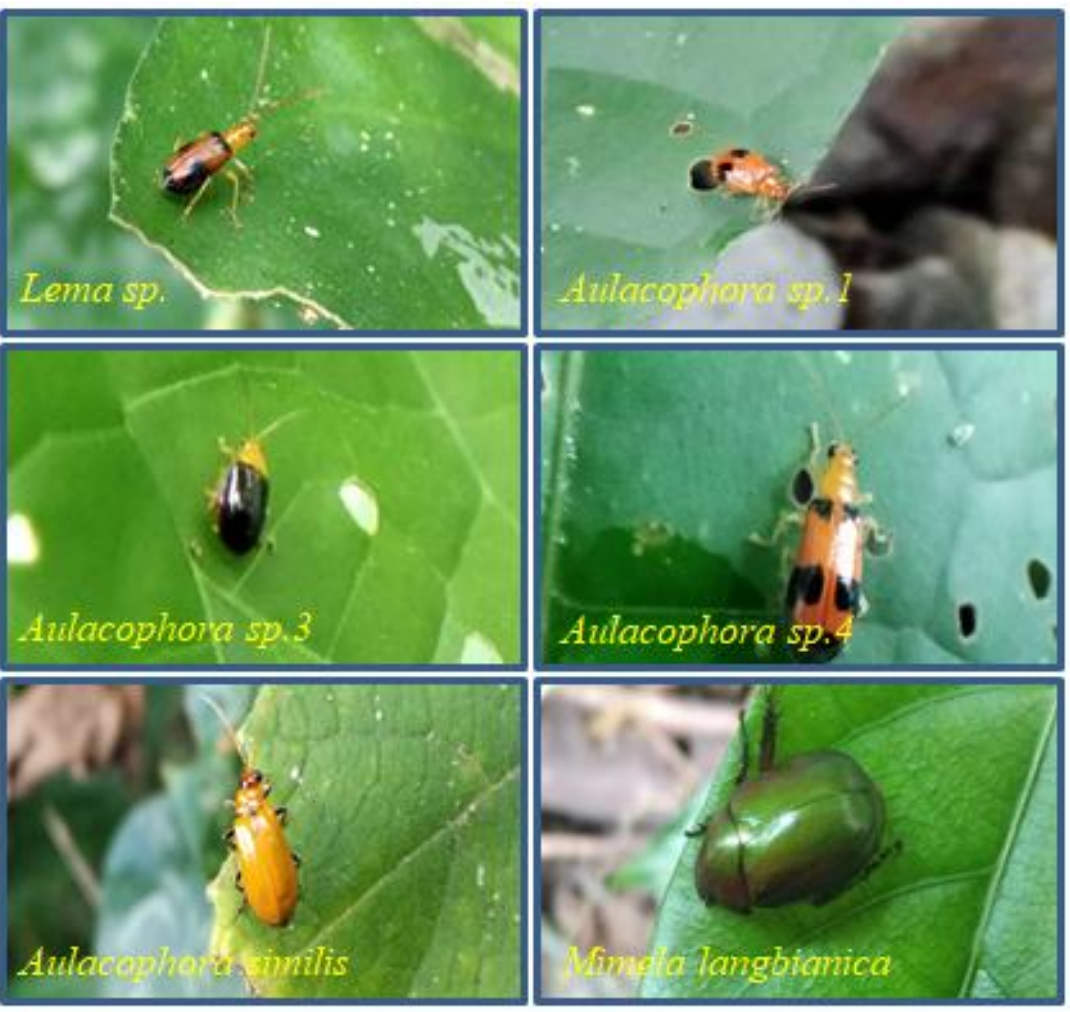

Gambar 3. Sampel spesies kumbang arboreal di TWA Suranadi 
Secara keseluruhan, kekayaan spesies kumbang arboreal yang ditemukan di TWA Suranadi ini lebih tinggi dibandingkan dengan total spesies dari famili kumbang sungut panjang di Hutan Pendidikan Gunung Walat, Jawa Barat. Ukuran kekayaan spesiesnya adalah 16 spesies (Sataral et al., 2015). Namun jika dibandingkan dengan yang ditemukan di Jambi dan Gunung Bwakareang Sulawesi Selatan, ukuran kekayaan spesies dari hasil penelitian ini masih lebih rendah. Secara berurutan total spesies dari famili Cerambycidae adalah 28 spesies, dan 37 spesies dari famili Carabidae \& Staphylinidae (Atmowidi \& Noerdjito, 2016; Qodri et al., 2016). Di perkebunan kelapa sawit, Kalimantan Tengah dan Sungai Mamberamo Papua juga telah ditemukan kekayaan spesies yang lebih tinggi. Secara berurutan, ada 24 dan 28 spesies yang tercatat di kedua lokasi tersebut (Rizal et al., 2019; Sa'roni et al., 2019). Adanya perbedaan kekayaan spesies dari ordo Coleoptera dibandingkan dengan di kawasan lain di Indonesia terkait erat dengan adanya perbedaan kondisi lingkungan, baik secara biologis, fisika maupun kimiawi. Ini memberikan efek pada munculnya perbedaan daya dukung lingkungan pada masing-masing kawasan.

Adanya perbedaan kekayaan spesies juga dapat disebabkan oleh perbedaan posisi geografis. TWA Suranadi yang merupakan salah satu kawasan di Pulau Lombok secara otomatis termasuk kawasan peralihan (Ali \& Heaney, 2021). Ini mengacu pada distribusi fauna di Indonesia berdasarkan garis Wallace di Selat Lombok dan garis Weber di timur Maluku. Selain itu, TWA Suranadi juga termasuk kawasan yang berada di pulau dengan sejarah geologi yang unik. Sehingga diklasifikasikan ke dalam kelompok yang disebut Lesser Sunda Islands. Ukuran pulau yang relatif lebih kecil dan terisolir dari daratan lain yg lebih besar memicu tingginya kekayaan spesies kumbang endemik. Sejauh ini sudah tercatat 11 spesies endemik. Dua spesies dari famili Chrysomelidae, enam spesies dari famili Staphylinidae, dan tiga spesies dari famili Cerambycidae. Spesies-spesies ini memiliki nama yang diturunkan dari nama Lombok, Sesaot, Batu Koq dan Sapit. Dari hasil penelitian ini, ditemukan 12 spesies yang masih menggunakan nama genus untuk membedakannya dengan spesies lainnya. Ada potensi bahwa di antara spesies-spesies tersebut terdapat spesies endemik yang belum terdeskripsi.

Informasi terkait kekayaan spesies kumbang arboreal ini menunjukkan bahwa proses ekologis yang terjadi di TWA Suranadi lebih kompleks dari yang telah diketahui sebelumnya. Ini dikarenakan peran dari kumbang arboreal yang penting dalam proses aliran energi dan siklus materi atau biogeokimia di habitatnya. Kumbang arboreal dewasa umumnya bersifat herbivore karena memanfaatkan berbagai bagian tumbuhan sebagai sumber nutrisinya (Huynh et al., 2017). Selama pengamatan, tidak sedikit spesies yang ditemukan di permukaan daun. Banyak bagian daun hilang, baik yang bolong-bolong ataupun yang bagian pinggir daun sampai bagian tengah hilang karena dimanfaatkan sebagai sumber energi dan materi oleh spesies tersebut. Ini sangat penting bagi predator yang tidak mampu secara langsung mengambil energi dan materi dari tumbuhan. Predator ini pun pada prosesnya akan dimangsa oleh predator lain dengan fungsi trofik yang lebih tinggi, dan terbentuk proses alamiah yang disebut dengan perpindahan energi dan materi dari organisme satu ke organisme lainnya. Fungsi ekologis kumbang arboreal tentunya tidak hanya sebatas sebgai "jembatan penghubung" antara produsen dan predatornya namun juga berperan pada aspek lain. Beberapa di antaranya adalah $\mathrm{CO}_{2}$ yang dilepaskan ke lingkungan dapat dimanfaatkan oleh tumbuhan di sekitarnya, dan kotorannya dapat membantu menjaga kesuburan tanah (Gray et al., 2021).

\section{Potensi sebagai sumber belajar sains SD}

Produk sains yang didapatkan dari hasil penelitian terkait kekayaan spesies kumbang arboreal di TWA Suranadi berpotensi untuk dijadikan sebagai sumber belajar sains di SD. Terdapat total 33 subtema dari 16 tema potensial yang pembelajarannya dapat memanfaatkan produk sains dari hasil penelitian tersebut (Tabel 1). Mereka terdistribusi pada pembelajaran sains di kelas 1 sampai dengan kelas 6. Kelas 1 terdiri atas 4 subtema dari 2 tema yaitu Tema 6 Lingkungan Bersih, Sehat dan Asri dan Tema 7 Benda, Hewan dan Tanaman di Sekitarku. Kelas 2 terdiri atas 5 subtema dari 4 tema yaitu Tema 2 Bermain di Lingkunganku, Tema 5 Pengalamanku, Tema 6 Merawat Hewan dan Tumbuhan dan Tema 7 Kebersamaan. Kelas 3 terdiri dari 4 subtema dari 2 
tema yaitu Tema 1 Pertumbuhan dan Perkembangan Makhluk Hidup dan Tema 2 Menyayangi Tumbuhan dan Hewan. Kelas 4 terdiri atas 8 subtema dari 3 tema yaitu Tema 3 Peduli Terhadap Makhluk Hidup, Tema 8 Daerah Tempat Tinggalku dan Tema 9 Kayanya Negeriku. Kelas 5 terdiri atas 9 subtema dari 3 tema yaitu Tema 1 Organ Gerak Hewan dan Manusia, Tema 5 Ekosistem dan Tema 8 Lingkungan Sahabat Kita. Adapun kelas 6 terdiri atas 3 subtema dari 2 tema yaitu Tema 1 Selamatkan Makhluk Hidup dan Tema 3 Tokoh dan Penemuan.

Tabel 1. Tema dan subtema potensial serta tingkat kesesuaiannya dengan konsep kekayaan spesies kumbang arboreal di TWA Suranadi

\begin{tabular}{|c|c|c|c|}
\hline No & Tema dan Subtema di SD & Skor & Kategori \\
\hline \multicolumn{4}{|c|}{ Kelas 1} \\
\hline \multirow[t]{3}{*}{1} & Tema 6 Lingkungan Bersih, Sehat dan Asri & & \\
\hline & Subtema 2 Lingkungan sekitar rumahku & 1 & Sangat kurang sesuai \\
\hline & Subtema 4 Berkerjasama menjaga kebersihan dan kesehatan lingkungan & 1 & Sangat kurang sesuai \\
\hline \multirow[t]{3}{*}{2} & Tema 7 Benda, Hewan dan Tanaman di Sekitarku & & \\
\hline & Subtema 1 Benda hidup dan benda tak hidup di sekitarku & 4 & Sesuai \\
\hline & Subtema 2 Hewan di sekitarku & 4 & Sesuai \\
\hline \multicolumn{4}{|c|}{ Kelas 2} \\
\hline \multirow[t]{2}{*}{3} & Tema 2 Bermain di Lingkunganku & & \\
\hline & Subtema 4 Bermain di tempat wisata & 1 & Sangat kurang sesuai \\
\hline \multirow[t]{2}{*}{4} & Tema 5 Pengalamanku & & \\
\hline & Subtema 4 Pengalamanku di tempat wisata & 1 & Sangat kurang sesuai \\
\hline \multirow[t]{3}{*}{5} & Tema 6 Merawat Hewan dan Tumbuhan & & \\
\hline & Subtema 1 Hewan di sekitarku & 4 & Sesuai \\
\hline & Subtema 2 Merawat hewan & 3 & Cukup sesuai \\
\hline \multirow[t]{2}{*}{6} & Tema 7 Kebersamaan & & \\
\hline & Subtema 4 Kebersamaan di tempat wisata & 1 & Sangat kurang sesuai \\
\hline \multicolumn{4}{|c|}{ Kelas 3} \\
\hline \multirow[t]{3}{*}{7} & Tema 1 Pertumbuhan dan Perkembangan Makhluk Hidup & & \\
\hline & Subtema 1 Ciri-ciri makhluk hidup & 2 & Kurang sesuai \\
\hline & Subtema 3 Pertumbuhan hewan & 2 & Kurang sesuai \\
\hline \multirow[t]{3}{*}{8} & Tema 2 Menyayangi Tumbuhan dan Hewan & & \\
\hline & Subtema 2 Manfaat hewan bagi kehidupan manusia & 4 & Sesuai \\
\hline & Subtema 4 Menyayangi hewan & 3 & Cukup sesuai \\
\hline \multicolumn{4}{|c|}{ Kelas 4} \\
\hline \multirow[t]{2}{*}{9} & Tema 3 Peduli Terhadap Makhluk Hidup & & \\
\hline & Subtema 1 Hewan dan tumbuhan dilingkungan rumahku & 2 & Kurang sesuai \\
\hline & Subtema 2 Keberagaman makhluk hidup di lingkunganku & 5 & Sangat sesuai \\
\hline \multirow{3}{*}{10} & Subtema 3 Ayo cintai lingkungan & 3 & Cukup sesuai \\
\hline & Tema 8 Daerah Tempat Tinggalku & & \\
\hline & Subtema 1 Lingkungan tempat tinggalku & 2 & Kurang sesuai \\
\hline \multirow{5}{*}{11} & Subtema 2 Keunikan daerah tempat tinggalku & 3 & Cukup sesuai \\
\hline & Subtema 3 Aku bangga dengan daerah tempat tinggalku & 1 & Sangat kurang sesuai \\
\hline & Tema 9 Kayanya Negeriku & & \\
\hline & Subtema 2 Pemanfaatan kekayaan alam di indonesia & 4 & Sesuai \\
\hline & Subtema 3 Pelestarian kekayaan sumber daya alam di indonesia & 3 & Cukup sesuai \\
\hline \multicolumn{4}{|c|}{ Kelas 5} \\
\hline \multirow[t]{4}{*}{12} & Tema 1 Organ Gerak Hewan dan Manusia & & \\
\hline & Subtema 1 Organ gerak hewan & 2 & Kurang sesuai \\
\hline & Subtema 2 Manusia dan lingkungan & 2 & Kurang sesuai \\
\hline & Subtema 3 Lingkungan dan manfaatnya & 3 & Cukup sesuai \\
\hline \multirow[t]{4}{*}{13} & Tema 5 Ekosistem & & \\
\hline & Subtema 1 Komponen ekosistem & 5 & Sangat sesuai \\
\hline & Subtema 2 Hubungan makhluk hidup dalam ekosistem & 4 & Sesuai \\
\hline & Subtema 3 Keseimbangan ekosistem & 4 & Sesuai \\
\hline \multirow[t]{4}{*}{14} & Tema 8 Lingkungan Sahabat Kita & & \\
\hline & Subtema 1 Manusia dan lingkungan & 3 & Cukup sesuai \\
\hline & Subtema 2 Perubahan lingkungan & 2 & Kurang sesuai \\
\hline & Subtema 3 Usaha pelestarian lingkungan & 3 & Cukup sesuai \\
\hline
\end{tabular}




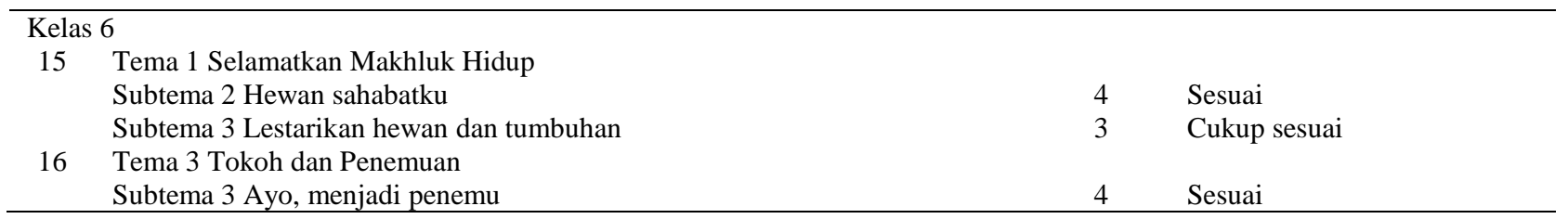

Berdasarkan Tabel 1 dapat diketahui bahwa terdapat 5 subtema dengan kategori sangat kurang sesuai untuk menggunakan konsep kekayaan spesies arboreal sebagai bahan ajar. Subtemasubtema ini adalah Subtema 2 Lingkungan sekitar rumahku dan Subtema 4 Berkerjasama menjaga kebersihan dan kesehatan lingkungan pada kelas I; Subtema 4 Bermain di tempat wisata \& Subtema 4 Pengalamanku di tempat wisata pada kelas II; dan Subtema 3 Aku bangga dengan daerah tempat tinggalku pada kelas IV. Sementara itu, kategori kurang sesuai terdiri dari 7 subtema. Subtemasubtema ini adalah Subtema 1 Ciri-ciri makhluk hidup \& Subtema 3 Pertumbuhan hewan pada kelas III; Subtema 1 Hewan dan tumbuhan dilingkungan rumahku \& Subtema 1 Lingkungan tempat tinggalku pada kelas IV; dan Subtema 1 Organ gerak hewan, Subtema 2 Manusia dan lingkungan \& Subtema 2 Perubahan lingkungan pada kelas V. subtema-subtema dengan dua kategori ini memiliki keterkaitan secara tidak langsung terhadap konsep keanekaragaman kumbang arboreal di TWA Suranadi. Konsep ini sendiri masih dapat digunakan pada pembelajaran, namun hanya terbatas pada TWA Suranadi sebagai tempat wisata dan kumbagn arboreal sebagai bagian dari lingkungan di sekitar tempat tinggal, kumbang arboreal sebagai contoh makhluk hidup khususnya hewan dengan karakteristik tertentu dan indikator perubahan lingkungan.

Berbeda dengan subtema yang tidak terkait secara langsung karena hanya beririsan pada sebagian kecil aspek tertentu, subtema-subtema dengan kategori cukup sesuai dan sesuai memiliki keterkaitan langsung dengan konsep kekayaan spesies kumbang arboreal di TWA Suranadi. Subtema dengan kategori cukup sesuai terdiri atas Subtema 2 Merawat hewan pada kelas II; Subtema 4 Menyayangi hewan pada kelas III; Subtema 3 Ayo cintai lingkungan, Subtema 2 Keunikan daerah tempat tinggalku \& Subtema 3 Pelestarian kekayaan sumber daya alam di indonesia pada kelas IV; Subtema 3 Lingkungan dan manfaatnya, Subtema 1 Manusia dan lingkungan \& Subtema 3 Usaha pelestarian lingkungan pada kelas $\mathrm{V}$; dan
Subtema 3 Lestarikan hewan dan tumbuhan pada kelas VI. Walaupun tidak tersurat, namun kekayaan spesies kumbang arboreal di merupakan informasi yang sangat penting bagi manajemen konservasi di kawasan TWA Suranadi. Adapun subtema-subtema dengan kategori sesuai, kekayaan spesies kumbang arboreal di TWA Suranadi dapat secara langsung digunakan pada proses pembelajaran. Misalnya Subtema 2 Hewan di sekitarku. Kumbang merupakan hewan dengan keragaman yang tinggi. Bagi peserta didik SD di Pulau Lombok, khususnya yang berlokasi di sekitar TWA Suranadi, kumbang arboreal tersebut lebih kontekstual dibandingkan dengan contohcontoh hewan lain seperti gajah, orang utan, burung cenderawasih, jerapah dan badak bercula satu.

Hewan-hewan lain seperti cicak, kecoa, nyamuk dan ayam sangat umum ditemukan di lingkungan sekitar peserta didik. Namun ini sudah dikenalkan oleh orang tua, kerabat dan masyarakat sekitar rumah, sehingga tidak perlu diperkenalkan lagi di bangku sekolah. Adapun kekayaan spesies kumbang arboreal ini ada di TWA Suranadi, namun tidak mereka kenal. Ini menyebabkan timbulnya sikap acuh pada diri peserta didik dan tidak memiliki literasi konservasi karena pengenalan melalui pembelajaran sains telah terbukti dapat meningkatkan dan mengembangkan literasi konservasi peserta didik (Sari et al., 2020; Sunarsih et al., 2020). Ini akan berdampak positif terhadap upaya konservasi khususnya di TWA Suranadi karena semakin banyak elemen masyarakat yang terlibat karena kesadarannya sendiri, maka upaya pelestarian sumberdaya hayati khususnya kumbang arboreal akan terlaksana secara lebih optimal. Efek turunanya adalah proses-proses ekologi kawasan akan terawetkan dan kegiatan wisata yang merupakan salah satu penopang ekonomi masayarakt sekitar dapat terjadi secara berkelanjutan. Selain itu, fungsi kawasan TWA Suranadi pada aspek pendidikan juga terekspresi mellaui pemanfaatan kompenen ekosistem yang ada menjadi sumber belajar sains SD. 
Subtema lain yang dapat memanfaatkan konsep kekayaan spesies kumbang arboreal sebagai sumber belajar sains SD adalah Subtema 2 Keberagaman makhluk hidup di lingkunganku pada kelas IV dan Subtema 1 Komponen ekosistem pada kelas V. kedua subtema ini memiliki tingkat kesesuaian yang paling tinggi dengan kategori sangat sesuai (Tabel 1). Hal ini dikarenakan kekayaan spesies merupakan variabel penting pada kajian keanekaragaman makhluk hidup dan sistem ekologi (ekosistem), sehingga menjadi produk sains yang "wajib" dikuasai oleh peserta didik. Dari aspek keanekaragaman, kumbang merupakan kelompok hewan yang paling kaya akan spesies. Terutama dari famili Chrysomelidae yang bersifat arboreal dan masih sedikit diketahui di Pulau Lombok (Beitr \& Serie, 2008), termasuk di TWA Suranadi. Jumlah spesies kumbang yang telah dideskripsikan lebih sedikit dari jumlah sebenarnya. Ini dibuktikan dari adanya laporanlaporan terbaru tentang pendeskripsian speises yang belum dikenal sebelumnya (Gildenkov, 2020). Adapun dari aspek ekosistem, kumbang merupakan komponen biotik ekosistem yang penting dalam menjaga keberlangsungan atau keberlanjutan proses-proses ekologi di habitatnya. Dengan mempelajari kekayaan spesies kumbang arboreal di TWA Suranadi, peserta didik dapat lebih mengenal lingkungannya sendiri, khususnya peserta didik di sekitar kawasan.

\section{Kesimpulan}

Kekayaan spesies kumbang (Insecta: Coleoptera) arboreal di TWA Suranadi adalah 18 spesies yang diwakili oleh 5 famili. Famili Chrysomelidae memiliki kekayaan spesies tertinggi yaitu 12 spesies. Spesies-spesies ini adalah Lema sp., Aulacophora similis, Aulacophora quadrimaculata, Aulocophora sp.1, Aulocophora sp.2, Aulocophora sp.3, Aulocophora sp.4, Aulocophora sp.4 Aulocophora sp.5, Parchicola sp., Podontia sp., Altica cyanea dan Lilioceris sp. Dari famili Rutelidae ada dua spesies yaitu Mimela langbianica, dan Mimela sp. Famili Scarabaeidae diwakili oleh spesies Exopholis hypoleuca, Protaetia fruhstorferi dan Ontophagus taurus. Famili Cerambycidae dan Erotylidae masing-masing satu spesies yaitu Leptura sp. dan Languriini sp. Hasil penelitian kekayaan spesies kumbang ini berpotensi untuk dijadikan sumber belajar bagi peserta didik di SD. Terdapat dua subtema yang sangat sesuai yaitu Subtema 2 Keberagaman makhluk hidup di lingkunganku dan Subtema 1 Komponen ekosistem.

\section{Ucapan Terima kasih}

Terima kasih kami sampaikan kepada TIMBON - Rizki Regina Kawirian, Irmayani, Nova Fitriani Wahdah - atas bantuannya selama pengumpulan sampel dan data di lapangan.

\section{Referensi}

Ali, J. R., \& Heaney, L. R. (2021). Wallace's line, Wallacea, and associated divides and areas: history of a tortuous tangle of ideas and labels. Biological Reviews, 96(3), 922-942. https://doi.org/10.1111/brv.12683

Atmowidi, T., \& Noerdjito, W. A. (2016). Diversity and abundance of Cerambycid beetles in the four major land-use types found in Jambi Province, Indonesia. HAYATI Journal of Biosciences, 23(2), 5661.

https://doi.org/10.1016/j.hjb.2016.06.001

Beitr, S., \& Serie, N. (2008). New and poorly known Chrysomelidae (Coleoptera) from the islands of Bali and Lombok (Indonesia). Stuttgarter Beiträge Zur Naturkunde A, 1, 431-434.

Borror, D. J., Triplehon, C. A., \& Johnson, N. F. (1992). Pengenalan Pelajaran Serangga. In Edisi Keenam. Yogayakarta: Gadjah Mada University Press.

Dindal, D. L. (1990). Soil Biology Guide. New York: Wiley.

Domingo, J. G. (2021). Cognitive Skills Achievement in Mathematics of the Elementary Pre-Service Teachers Using Piaget's Seven Logical Operations. Turkish Journal of Computer and Mathematics Education (TURCOMAT), 12(4), 435-440. https://doi.org/10.1017/S003060531200162 7 
Ettema, C., Coleman, D., \& Vellidis, G. (1998). Spatiotemporal distribution of bacterivorous nematodes and soil resources in a restored riparian wetland. Ecology, 79, 2721-2734.

Fikacek, M., Jia, F., \& Prokin, A. (2012). A review of the Asian species of the genus Pachysternum (Coleoptera: Hydrophilidae: Sphaeridiinae). Zootaxa, 3219, 1-54. https://doi.org/10.11646/zootaxa.3219.1.1

Gildenkov, M. Y. (2020). Eight new species of the genus Carpelimus Leach, 1819 from Indonesia (Coleoptera: Staphylinidae: Oxytelinae ). Russian Entomological Journal, 29(1), 53-60. https://doi.org/10.15298/rusentj.29.1.07

Gray, C., Ma, A., McLaughlin, O., Petit, S., Woodward, G., \& Bohan, D. A. (2021). Ecological plasticity governs ecosystem services in multilayer networks. Communications Biology, 4(1), 1-7. https://doi.org/10.1038/s42003-020-015473

Harding, W. A., \& Moore, J. P. (1926). The Fauna of British India, including Ceylon and Burma (Vol. 3). Today and Tomorrow Publisher.

Huynh, M. P., Meihls, L. N., Hibbard, B. E., Lapointe, S. L., Niedz, R. P., Ludwick, D. C., \& Coudron, T. A. (2017). Diet improvement for western corn rootworm (Coleoptera: Chrysomelidae) larvae. PloS One, 12(11), e0187997. https://doi.org/10.1371/journal.pone.01879 97

Ilhamdi, M. L., Idrus, A. A. L., Santoso, D., Hadiprayitno, G., \& Syazali, M. (2021). Species richness and conservation priority of dragonflies in the Suranadi Ecotourism Area, Lombok, Indonesia. Biodiversitas, 22(4), 1846-1852. https://doi.org/10.13057/biodiv/d220430

Ilhamdi, M. L., Idrus, A. Al, \& Santoso, D. (2018). Diversity of species and conservation priority of butterfly at Suranadi Natural Park of West Lombok, Indonesia. Biosantifika: Journal of Biology \& Biology Education, 10(1), $\quad$ 48-55. https://doi.org/10.15294/biosaintifika.v10i1 .10695

Ilhamdi, M. L., Idrus, A. Al, Syazali, M., \& Raksun, A. (2021). Species richness of beetle (Hexapoda: Coleoptera) in Suranadi Nature Recreation Park, Lombok Island. Jurnal Pijar MIPA, 16(4), 535-541. https://doi.org/10.29303/jpm.v16i4.2345

Ilhamdi, M. L., \& Syazali, M. (2021). Diversity of Soil Arthropods in Suranadi Nature Park, Lombok, and its role on science lesson in elementary and secondary school. Jurnal Biologi Tropis, 21(3), 926 - 937. https://doi.org/10.29303/jbt.v21i3.2990

Jäch, M. A., Díaz, J. A., \& Skale, A. (2013). The Hydraenidae (Coleoptera) of the republic of Singapore. The Raffles Bulletin of Zoology, 61(1), 53-71.

Löbl, I. (2015). On the Scaphidiinae (Coleoptera: Staphylinidae) of the Lesser Sunda Islands. Revue Suisse de Zoologie, 122(1), 75-120. https://doi.org/10.5281/zenodo.14582

Qodri, A., Raf, R., \& Noerdjito, W. A. (2016). Diversity and Abundance of Carabidae and Staphylinidae (Insecta: Coleoptera) in four montane habitat types on Mt. Bawakareang, SOuth Sulawesi. HAYATI Journal of Biosciences, 23, 22-28. https://doi.org/10.1016/j.hjb.2016.04.002

Riedel, A., Tänzler, R., Balke, M., Rahmadi, C., \& Suhardjono, Y. R. (2014). Ninety-eight new species of Trigonopterus weevils from Sundaland and the Lesser Sunda Islands. ZooKeys, 467, 1-162. https://doi.org/10.3897/zookeys.467.8206

Rizal, A., Suryana, A. A. H., Rosidah, \& Nurruhwati, I. (2019). Diversity and the abundance of the insect of Coleoptera orders at Mamberamo river bank of Papua Province, Indonesia. World Scientific News, 133, 132-144. 
Rohyani, I. S. (2020). Community structure analysis of soil insects and their potential role as bioindicators in various ecosystem types in Lombok, West Nusa Tenggara, Indonesia. Biodiversitas, 21(9), 4221-4227. https://doi.org/10.13057/biodiv/d210937

Ruzzier, E. (2018). A New Species of Lycidomorda Horák, 2007 (Coleoptera: Mordellidae: Mordellistenini) from Sulawesi (Celebes: Indonesia). The Coleopterists Bulletin, 72(1), 93-95. https://doi.org/10.1649/0010-065X-72.1.93

Sa'roni, S. M., Prabowo, R., Sahari, B., \& Buchori, D. (2019). Diversity of dung beetle (Coleoptera: Scarabaeidae) in oil palm agropasture ecosystem in West Kotawaringin Regency, Central Kalimantan, Indonesia Diversity of dung beetle ( Coleoptera: Scarabaeidae ) in oil palm agropasture ecosystem in West Kotawaringin. IOP Conference Series: Earth and Environmental Science, 468, 1-9. https://doi.org/10.1088/17551315/468/1/012006

Sari, N. P., Walid, A., Studi, P., Pengetahuan, I., Sains, J., Tarbiyah, F., Agama, I., \& Negeri, I. (2020). Pengembangan modul pembelajaran IPA berbasis etnosains materi interaksi makhluk hidup dengan lingkungannya untuk menanamkan jiwa konservasi siswa kelas VII SMP. BIOEDU : Jurnal Pendidikan Biologi, 5(2), 62 73. https://doi.org/10.32938/jbe.v5i2.554

Sataral, M., Atmowidi, T., \& Noerdjito, W. A. (2015). Diversity and abundance of longhorn beetles (Coleoptera:
Cerambycidae) in Gunung Walat Educational Forest, West Java, Indonesia. Journal of Insect Biodiversity, 3(17), 1-12.

Shahabuddin, S., Hidayat, P., Noerdjito, W. A., \& Manuwoto, S. (2005). Research on insect biodiversity in Indonesia: Dung beetles (Coleoptera: Scarabaeidae) and its role in ecosystem. Biodiversitas Journal of Biological Diversity, 6(2), 141-146.

Sulaeman, N. F., Nuryadin, A., Widyastuti, R., \& Subagiyo, L. (2020). Air quality index and the urgency of environmental education in Kalimantan. Jurnal Pendidikan IPA Indonesia, 9(3), 371-383. https://doi.org/10.15294/jpii.v9i3.24049

Sunarsih, S., Rahayuningsih, M., \& Setiati, N. (2020). The Development of Biodiversity Module Using Discovery Learning Based on Local Potential of Wonosobo. Journal of Innovative Science Education, 9(1), 1-11.

Tatsuya, N., \& Yaheita, Y. (2015). Additional notes on the Stenopterine Fauna (Coleoptera, Cerambycidae) of the Island of Lombok, Indonesia. Elytra, 5(1), 207-216.

Yokoi, Y. (2015). Notes on the Callidiopini (Coleoptera, Cerambycidae) across the Lombok Strait. Elytra, 5(1), 185-205.

Yoshitomi, H. (2014). Phanodesta celebessa (Coleoptera: Trogossitidae): A New Species from Sulawesi, Indonesia. Japanese Journal of Systematic Entomology, 20(2), 219-223. 